\title{
Narrating the impacts of climate change for urban health governance in Guangzhou, China
}

\section{Jieling Liu}

To cite this article: Jieling Liu (2020): Narrating the impacts of climate change for urban health governance in Guangzhou, China, Cities \& Health, DOI: 10.1080/23748834.2019.1701945

To link to this article: https://doi.org/10.1080/23748834.2019.1701945

册 Published online: 06 Jan 2020.

Submit your article to this journal 2

Џll Article views: 4

Q View related articles $\sqsubset$

View Crossmark data $₫$ 


\section{Narrating the impacts of climate change for urban health governance in Guangzhou, China}

\begin{abstract}
Jieling Liu (D)
ABSTRACT

Global anthropogenic climate change imposes high risks on environmental sustainability and public health. The paper starts by illustrating the climate change impacts on health in Guangzhou, a rapidly expanding urban hub in China. Next, this paper investigates the institutional narratives of the climate-health nexus in Guangzhou by analysing relevant policies and work plans. Finally, the paper identifies knowledge gaps to which the paper proposes ways to improve urban health governance. The methodology includes a literature review on the health impacts of climate change, in-depth interviews with the environment and health policymakers in Guangzhou, and a policy archive review. Despite the scientific evidence of positive linkages between climate change impacts on health in Guangzhou, institutional narratives and policy responses on this linkage appear to be lacking, insufficient, or delayed. The outcomes of our narrative analysis point to the possibility that this could be due to the top-down tradition of urban governance, a lack of effective interdepartmental and cross-sectoral collaboration mechanisms, and the overall lack of institutional support for implementing the 'Health in All Policies' framework. The paper suggests health policymaking in Guangzhou to narrate climate change impacts more openly, scientifically to the public, and to address urgent health risks more systematically.
\end{abstract}

ARTICLE HISTORY

Received 17 August 2019

Accepted 3 December 2019

\section{KEYWORDS}

Climate change impacts; institutional narratives; urban health governance; systemic approaches; resilience; China

\section{Introduction}

Scientific evidence of climate change and its impacts on health are essential for informing and enhancing policies and governance for urban health and wellbeing. However, such scientific findings, e.g. of heatwaves, air pollution, and extreme weather events, and climate scenarios, often appear to be impersonal and obscure for most non-scientific public readers, including policymakers in government institutions. How to translate scientific evidence into adaptation policies and action, therefore, has been an intriguing puzzle for academics, politicians, and practitioners alike. The resulting knowledge-action gap needs to be improved urgently to reduce the damage of disasters and enhance resilience for urban health. To do that, it is necessary first to understand how policymakers and policy-making institutions perceive and understand climate change impacts from scientific findings. Second, it is needed to know how they narrate their knowledge into policy and action, taking into account the specific geographical, environmental, socioeconomic, and political contexts. Following this process can help decision-makers get the information they need for formulating policies. Besides, it can also help academics and practitioners better understand what knowledge to produce and how to present and communicate the scientific findings of climate change impacts for enhancing urban health and wellbeing management.
Narrative, by the definition of the Oxford Dictionaries ${ }^{1}$, is 'a spoken or written account of connected events; a story.' In this paper, it is referred to 'institutional narratives of climate change and health linkages,' specifically as government institutions' written accounts of climate change impacts on health. At the UN summit in Copenhagen in 2009, some policy analysts viewed China as a factor of the 'Brokenhagen' - a weak agreement without commitments to emissions reductions (Doelle 2010). Six years after, the Chinese governments are viewed as actively responding to the international goal to mitigate and to adapt to climate change. During this period, Beijing has enhanced its institutional narratives on environmental challenges and sustainability transformation in comparison to other governance issues. 'Ecological civilisation', for instance, has evolved from a general 'future-oriented guiding principle' according which the country needs to 'put our relationship with nature in a new perspective' (China Daily 2007), to an official narrative that is 'vital' and 'of fundamental importance for China's sustainable development' (China Daily 2007). Institutional narratives such as the ecological civilisation reflect organisational identity, values, and political will. Hence, they are vital to understanding better how Chinese governments seek to make progress in these fields. 
This paper applies the institutional narrative analysis of climate change impacts on urban health. Guangzhou is chosen as an example of Chinese local governments, to verify how institutional narratives influence urban health governance. This paper examines the current institutional narratives in Guangzhou. The paper suggested that systems thinking could help to make the climate change - health nexus narrative more comprehensive to the public., thereby contributing to informing the policy-making processes. I chose Guangzhou as an example of Chinese local governments because of its particular geographical, environmental, socio-economic, and political contexts. In particular, the increasing complexity of its urban systems functioning, and the pressing urgency to improve health management for 14 million urban residents under climate change is striking. I first conduct a fact-check of the climate change - health nexus in the urban contexts of megacity Guangzhou. Then, I lead a narrative analysis regarding the language and the way public administrations receive and recount these impacts and translate them into policies and contingency plans for urban health. The outcome of the analysis of the narratives shows that there is a wide gap between knowledge of and action on climate change and health issues. This paper, therefore, propose systems thinking for closing the knowledgeaction gap and making the climate-health nexus more comprehensible and prominent in urban governance for resilience to climate change.

\section{Objectives and methodological approach}

The main objectives of this paper are to two folds. First is to highlight the critical role of institutional narratives in communicating the scientific evidence on climate change into urban health governance in Guangzhou. The second is to propose a mechanism that may improve institutional narrative. As displayed in Figure 1, I begin by building a theoretical framework, which enables me to verify the various types of institutional narratives and the causal possibilities of outcomes. Then, I examine the ways through which institutions narrate the scientific evidence of climate change impacts on health and then translate them into urban health policies. The study is exemplified using the empirical case of Guangzhou. My analysis indicates a knowledge-action gap in the current policy and action response to the adverse impacts of climate change on health in Guangzhou. I propose systems thinking to be a way to improve institutional narratives of climate change impacts, thereby improving urban health governance. Systems thinking means taking into account the increasing complexity of the urban systems functioning; therefore, it is capable of helping urban health decision makers to view the urban health system of Guangzhou more comprehensively, including viewing it within the context of a changing climate. The Health in All Policies (HiAP) Framework for Action proposed by the World Health Organization (WHO), for example, has the potential to promote systems thinking. The HiAP Framework emphasises the systematic incorporation of health at all levels of policymaking in which policymakers primarily consider consequences on health systems, determinants of health, and wellbeing.

The content structure of this paper is the following. First, I recount the impacts of climate change, namely, intensified heatwaves, air pollution, and typhoons, to the health and wellbeing of urban residents of Guangzhou. I do so through reviewing scientific findings between 2008-2017, evidence of 10 years, records from the health administration, local meteorological services, climate and health research centres, projects and groups, as well as media reports. Second, I build a theoretical framework to verify the various types of institutional narratives and the causal possibilities of outcomes. Third, I scrutinize the narratives of local government and health institutions on the climatehealth nexus and the means of urban health

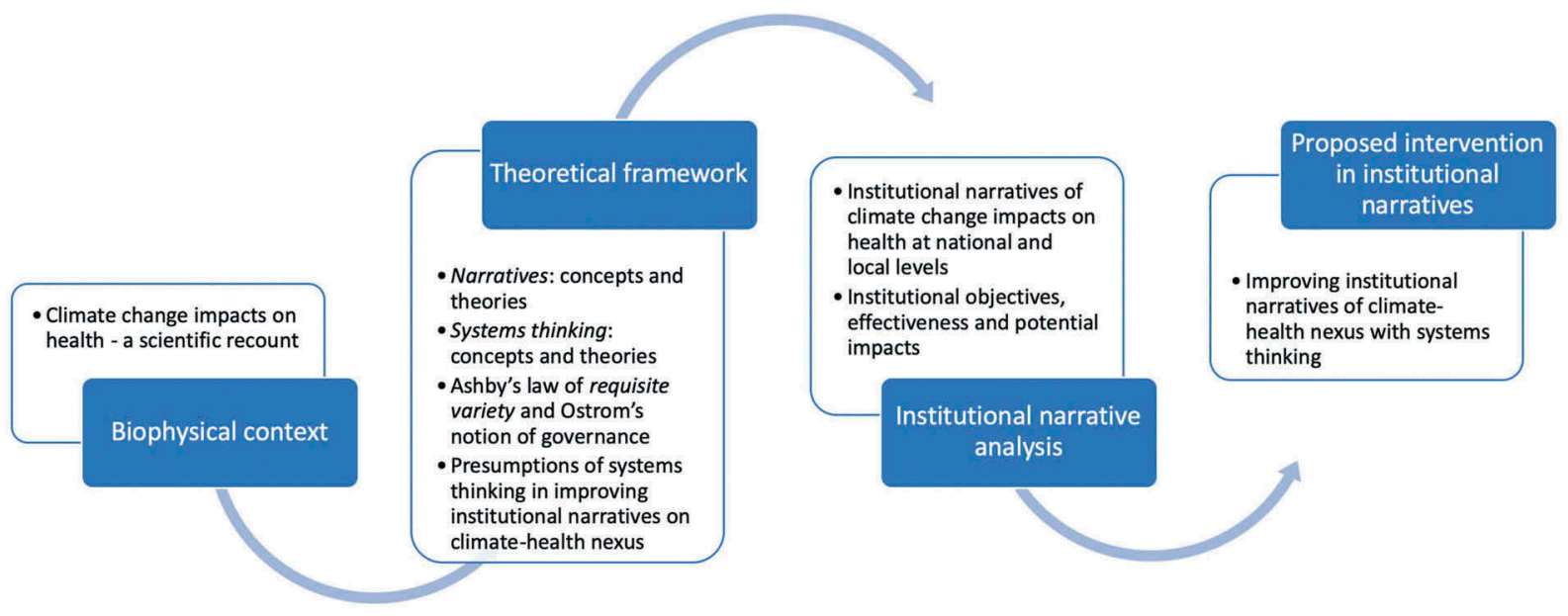

Figure 1. Research design of this paper. 
management through conducting a detailed policy narrative analysis, including the Healthy China 2030 Initiative and its sublevel ordinations. Specifically, this paper studies the language used in these policies regarding climate change impacts and urban health adaptation both at the national level (top-down, indirect command) and at the local level (direct command). This procedure means examining how institutional narratives frame climate change and health, how they position them in the policy documents, choice of wording, scopes, and perspectives. This procedure assesses the institutional narratives of climate change impacts on health governance in Guangzhou. Lastly, based on the assessment, this paper proposes systems thinking for improving urban health governance under climate change impacts.

\section{A scientific recount of climate change impacts on health at global scale and in Guangzhou}

Guangzhou, a fast-developing megacity that extends on the low-lying estuary of the Pearl River Delta (PRD) in South China, is home to more than 14 million urban inhabitants. Table 1 displays basic demographic and health information of Guangzhou. In addition to being one of the country's thriving economic hubs, Guangzhou features a climate of long warm summers and heavy precipitations due to its subtropical climate and monsoon seasons. Over the last few decades, Guangzhou has rapidly expanded, and the urban population grew dramatically. In the meantime, the municipal meteorological department of Guangzhou has recorded intensified heatwaves, typhoons, and air pollution in the PRD region, which have caused severe health damages and are very likely to display more significant impacts on human health and wellbeing (Committee of South China Regional Climate Change Assessment Report, 2012; C40). How central and local governments

Table 1. Basic demographic and health information, Guangzhou V.S. world, $2016 \sim 2017$.

\begin{tabular}{|c|c|c|}
\hline Demographic data category & Guangzhou & World average \\
\hline Population & $\sim 14$ million & 7.5 billion \\
\hline age of Urbanisation & & $54 \%$ \\
\hline Percentage of youth (ages $0-14$ ) & $17.21 \%$ & $26 \%$ \\
\hline $\begin{array}{l}\text { Percentage of elderly (ages } 65 \text { and } \\
\text { above) }\end{array}$ & & $4.48 \%$ \\
\hline Health aspects & All China & World average \\
\hline Life expectancy at birth (years) & 76.0 & 72 \\
\hline $\begin{array}{l}\text { Adult mortality rate, female (per } 1,000 \\
\text { people) }\end{array}$ & 72 & 123.17 \\
\hline $\begin{array}{l}\text { Adult mortality rate, male (per } 1,000 \\
\text { people) }\end{array}$ & 98 & 179.63 \\
\hline Public health expenditure (\% of GDP) & 5.5 & $\begin{array}{l}9 \text { in } \mathrm{OECD} \\
\text { countries }\end{array}$ \\
\hline $\begin{array}{l}\text { Under-five mortality rate (per 1,000 live } \\
\text { births) }\end{array}$ & 10.7 & 40 \\
\hline \multicolumn{3}{|c|}{$\begin{array}{l}\text { Data source: Guangzhou Statistics Bureau, Guangdong Statistics Bureau, } \\
\text { UNDP Human Development Report 2016, Statista, The World Bank Data } \\
\text { Catalog, United Nations Population Division. World Population } \\
\text { Prospects: } 2017 \text { Revision, WHO Global Health Expenditure Database }\end{array}$} \\
\hline
\end{tabular}

perceive, narrate, and cope with climate change impacts for urban health in Guangzhou is an intricate central puzzle. This puzzle is especially evident, given China's strong central-local institutional and policy alignments on environmental governance and Guangzhou's position as the capital of the Cantonese region. This paper aims to resolve this intricate central puzzle.

Heatwaves - one of the most direct impacts of climate change on human health today, are currently exacerbated both in frequency and severity, imposing significant health risks on nearly $30 \%$ of the global population today (IPCC 2014, Mora et al. 2017). Heatwaves impose both physical and mental danger, such as heatstroke, depression, and anxiety (Berry et al. 2010), influencing especially the physically vulnerable and economically underprivileged population. Globally, different models have projected an increasing trend in the frequency, intensity and duration of heatwaves $\left(\geq 30^{\circ} \mathrm{C}\right)$, under both the highest and moderate greenhouse gas scenarios (Meehl and Tebaldi 2004). In China, the average temperature has had an above-global-average increase of $0.5 \sim 0.8^{\circ} \mathrm{C}$ over the last century (BMC Springer Nature n.d.). In Guangzhou, heatwaves have intensified in the last 60 years both in the frequency and duration (see Figure 2). They were three times more frequent during 2001-2010 than 1991-2000 and the heatwave season was also more than three times longer. In Guangzhou, the number of high-temperature days $\left(\geq 35^{\circ} \mathrm{C}\right)$ per year has been more than 30 days in recent decades. Each degree of temperature rise has increased 3.7\% mortality rate for the elderly ( $\geq 65$ years old) (Liang 2014), and it is likely to intensify in the future (Zhang et al. 2018). In addition, the annual number of hazy

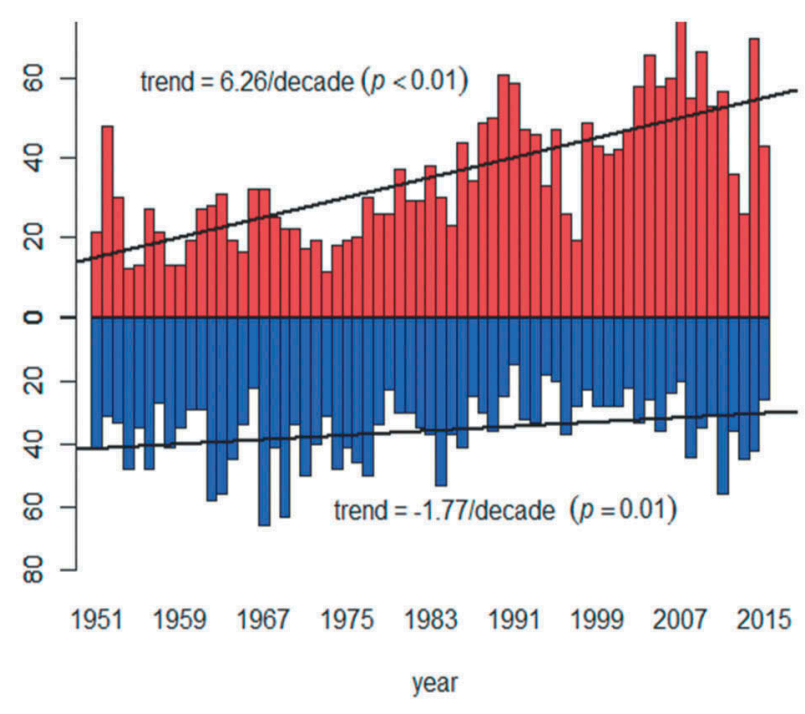

Figure 2. The number of extreme warm/cold days in Guangzhou over 1951-2015.

Note: The black lines indicate the linear trend. Figure source: Trends of Heat Waves and Cold Spells over 1951-2015 in Guangzhou, China (Zhang et al. 2017) 
days in Guangzhou has increased at a rate of 16.4 days per 10 years. The incidence of respiratory diseases during hazy days is about $15 \%$ higher than usual (Provincial Government of Guangdong 2011).

Another major urban health challenge to health is air pollution, which is induced primarily by fossilfuelled transport, energy, and industrial production systems. Air pollution typically causes heart disease, stroke, lung cancer, and both chronic and acute respiratory diseases (WHO n.d.). Fossil fuel consumption leads to both air pollution and atmospheric warming; the latter could reinforce the effect and duration of air pollution, worsening the already adverse health consequences and economic costs. Air pollution is the largest environmental cause of disease and death in the world today for causing an estimated 9 million premature deaths annually (Landrigan et al. 2018). Pollution from heavy vehicles in European Environment Agency (EEA) member countries costs 43-46 billion euros in health annually (EEA 2013). WHO Western Pacific and South East Asian regions, in which Guangzhou is located, accounts for $2 / 3$ of the world total death due to exposure from air pollution each year (WHO 2016).

In addition to intensified heatwaves and air pollution, Guangzhou is facing the potential increase of inundation from storm surge and flash floods, as sealevel continues to rise, and the frequency and intensity of tropical cyclones continue to increase due to global warming (IPCC 2014). Between 2013-2017, typhoons have caused an estimated 2000 deaths in the South East China region in which Guangzhou is located (State Council of China 2014-2018). Dengue fever, a common concern in Guangzhou in post-typhoon periods due to the stagnant groundwater and hot, humid weather, has been found appearing more frequently (Xiang et al. 2017). In addition, the increased intensities of tropical cyclones and rising sea levels globally are impacting the social, economic and environmental determinants of mental health (Fritze et al. 2008, Walsh et al. 2014), leading to severe mental health problems including fear and stress, post-disaster trauma, possibly even increased suicidal tendency (Berry et al. 2010). Presently, there is little research revealing the impacts of climate change on mental health in Guangzhou, or globally in general. The subject of mental health impacts merit further investigation.

In summary, existing research shows strong evidence of the complex climate change impacts - intensified heat waves, air pollution, and extreme weather events - on health globally as well as in Guangzhou, especially due to its compact and fast-expanding urban setting. These impacts tend to bring forth more significant damages for physically and economically vulnerable groups.

Despite emerging clarity of the scientific evidence, the fact that climate change-related mortality is on the rise may imply certain failure in narrating the scientific evidence and its complexity comprehensively in policymaking processes and incorporating them into policies and actions.

\section{Theoretical framework}

\section{Narratives: concepts and theories}

Merriam-Webster Dictionary ${ }^{2}$ defines narrative as either something that is narrated, e.g. story, account; or a way of presenting or understanding a situation or series of events that reflects and promotes a particular point of view or set of values. Barry and Elmes define narratives as 'thematic, sequenced accounts that convey meaning from implied author to implied reader' (1997, p. 431). In addition to reflecting societal values and cultural meanings at large, narratives also tend to be context-specific and always involve particular individuals and organizations (Lefsrud and Jennings 2013). Narratives reflect the ideas and understanding of the narrators about social-environmental issues, the relevance and impact of existing institutions, and the need for alternative ones (Patterson and Beunen 2019). Scholars have examined narratives for their constitutive power to produce social meaning and allocate power (Ewick and Silbey 1995).

The narrative theory assumes narrative to be a cognitive tool for situated understanding (Gerrig 1993), or in other words, to be a basic human strategy to make sense of the world. A key concern for narrative theorists is whether narrative as a way of thinking about or explaining the human experience is the opposite of scientific modes of explanation that characterize phenomena as impersonal instances of general covering laws. For example, in the narrative policy framework (NPF) studied by McBeth et al. (2014), an outstanding issue in the NPF is: policy documents are authored and devised with an audience in mind; however, narratives in these documents do not always correspond to how practitioners, scientists, or analysts view a particular policy issue. Hence, narratives vary depending on the individual or group who narrates, and there is no one standard on what could constitute 'the best narrative.' However, effective narratives do share two features, according to Barry and Elmes (1997): they establish credibility, and they create a sense of novelty or defamiliarization.

\section{Systems thinking: concepts and theories}

Systems thinking refers to a transdisciplinary conceptual framework rooted in the field of Cybernetics and informed by complex systems science, which has been significantly expanded in recent decades by research across the formal, natural, and social sciences (Best 2007, Chughtai and Blanchet 2016). Cities can be considered as complex adaptive systems, as Hancock and 
Duhl (1988) define: '(cities are) the example par excellence of complex systems: emergent, far from equilibrium, requiring enormous energies to maintain themselves, displaying patterns of inequality and saturated flow systems that use capacity in what appear to be barely sustainable but paradoxically resilient networks.' Cities are also referred to as complex adaptive systems by the International Science Council (ISC) program 'Urban Health and Wellbeing - A Systems Approach.' The program advocates a systems approach to recognize and to address the multiple values generated by the urban system for the health and wellbeing of its inhabitants (Gatzweiler et al. 2016). Systems thinking contributes to including different stakeholders and integrating different types of knowledge and strategies to address complex problems in cities, such as climate change impacts and health problems. The two are both increasingly referred by scholars as 'wicked problems' due to their high scientific and economic complexity with radical uncertainties (Horn and Weber 2007, Hannigan and Coffey 2011, Gibbon and Mensah 2012, Grundmann 2016).

\section{Narratives and systems thinking in public health governance and sustainability}

The law of requisite variety, also recognized as one of the most important principles of cybernetics, was formulated by Ross Ashby, a pioneer British cyberneticist and psychiatrist. In a nutshell, the law of requisite variety means that, in order to address the diverse range of problems in a complex adaptive system like the city, such as climate change impacts and health risks, there needs to be a repertoire of responses at least as nuanced as the problems being targeted (Ashby 1984). If the responses were more nuanced or diverse than the variety of the problems, then the management or governance measures would have been cost inefficient; on the other hand, If the responses were less nuanced or diverse than the variety of the problems, then the management or governance measures would have been invalid.

The importance of requisite variety - the acknowledgement of diversity and complexity in both the problems and the coping mechanisms in the system, was endorsed by Elinor Ostrom, a Nobel laureate in Economics for her analysis on common-pool resource (CPR) governance. ' ... Vincent, who had worked with Ross Ashby at the Palo Alto Center for Advanced Studies in the Behavioural Sciences in California where Vincent was an invited fellow in 1955, was convinced about the need for requisite variety. ... We became devoted to understanding institutional diversity and allowing for complexity where needed' (Toonen 2010). In her meta-analysis of empirical studies of CPR governance, such as the governance and management of irrigation, fisheries, and forest institutions around the world, she found extensive examples that illustrate the immense variety of specific rules. The Institutional Analysis and Development (IAD) framework that she developed later in her book Understanding Institutional Diversity was precisely based on the immense variety of institutions she identified in these empirical studies. The IAD framework guides researchers to decode and map the design and evaluate the effects of institutions that govern decision making and behaviour in collective action situations (Ostrom 2005).

Institutional narratives of the impacts of climate change on urban health occur during the policymaking process and influence policy outcomes. On the one hand, the embodied experience and value of governance institutions or individuals at multiple levels affect the way local participants understand, implement, modify, or ignore rules written by external officials in a top-down way (Medard and Geheb 2001). On the other hand, informal networks that bridge diverse types of knowledge and differences could promote successful environmental action and participation with a bottom-up gesture (Ingram et al. 2015). Therefore, theoretically speaking, systems thinking could contribute to including different stakeholders and integrating different types of knowledge and strategies before and at the policy-making process, thereby influencing the institutional narratives of climate change impacts on health, promoting governance institutions to address the climate-health nexus better and to make policies more comprehensively.

\section{Institutional narratives of climate change impacts on health}

Institutional narratives of climate change impacts and health can reveal policymakers' and the respective institutions' ability to perceive and deal with complex information, such as climate change and health nexus. Here I aim at revealing these institutional and policy narratives considering factors such as decisionmaking power, time, budget, and population scope. I begin with the assumption that policymakers produce all health policies with the overall goal of safeguarding or improving public health under climate change. Here, we briefly introduce the main healthrelated institutions engaged in understanding environmental causes and protecting public health in China. To examine how and to what extent the complex subject of climate change has been communicated to and has informed health policymaking, I focus on health-related institutions for the narrative analysis. At each level of government, they are:

- The national, provincial and municipal Health Commissions (at the national level, the National 
Health Commission and the Ministry of Health are de-facto the same institution), as well as their respective Centres for Disease Control and Prevention;

- The national, provincial, and municipal Development and Reform Commissions (DRC), which are the socio-economic master planning departments of each administration level. At each level, the health commissions and centres for disease control and prevention coordinate with the DRCs to carry out plans and policies. These plans and strategies are supposed to aim at delivering health, as well as economic development and environmental goals.

- Departments of other affairs at each level, such as Ministry/Departments of Housing and UrbanRural Development, Bureaus of meteorology, and others, are also involved.

The institutions mentioned above take the lead or participate in decision-making related to environmental causes and health governance at each administration level, depending on the specific health issues in focus. To fulfil critical environmental-health knowledge gaps, central and local governments deal with emerging or urgent health challenges in the forms of Science and Technology Major Research Projects. The institutional framework for health governance in
China is organized in a national-provincialmunicipal administration structure. This structure manifests itself as top-down ( $\mathrm{Gu}$ and $\mathrm{Wu} 2010)$. The institutional public health agenda of Guangzhou city includes managing public health and preventing diseases at present and envisioning and planning health in the future with the consideration of environmental and climate change. Table 2 lists examples of the institutional public health agenda of Guangzhou. The examples range from action plans, institutional capacity building activities, adaptation strategies to climate change, institutional reforms, major research projects to public weather service provision.

\section{Institutional narratives of climate change impacts and health at the national level}

\section{The national strategy for climate change adaptation}

The National Strategy for Climate Change Adaptation (State Council of China 2013) debuted during the COP 19 in Warsaw in 2013. The Strategy was the first and one of the most critical sets of climate change adaptation policies of the country. It outlines a systematic transition framework of work focus from climate change assessment to adaptation policymaking, and it serves as guidance for cities to make climate change adaptation plans at their respective level. Specifically,

Table 2. Key plans and policies addressing climate change and health at the national level in China.

\begin{tabular}{|c|c|c|c|}
\hline Functions & Example & Policymakers/institutions & Key words \\
\hline \multirow[t]{5}{*}{ Action plans } & $\begin{array}{l}\text { National Environmental Health Action Plan (2007-2015) } \\
\text { (NEHAP) } \\
\text { 国家环境与健康行动计划 } \\
\text { (2007年～2015年) }\end{array}$ & $\begin{array}{l}\text { Coordinated by the Ministry of Health, } \\
\text { jointly collaborated with sixteen } \\
\text { relevant ministries and agencies }\end{array}$ & $\begin{array}{l}\text { 'key factors' } \\
\text { 'striving to solve' } \\
\text { 'basic requirement and an } \\
\text { important task' } \\
\text { 'people-oriented governance' } \\
\text { 'harmonious socialist society' }\end{array}$ \\
\hline & $\begin{array}{l}\text { Action Plan on Prevention and Control of Air Pollution } \\
\text { (2013) } \\
\text { 国家大气污染防治行动计划 }\end{array}$ & The State Council & $\begin{array}{l}\text { 'entry point' } \\
\text { 'fundamental interest' } \\
\text { 'improve air quality' }\end{array}$ \\
\hline & $\begin{array}{l}\text { National Strategy for Climate Change Adaptation } \\
\text { (2013) } \\
\text { 国家适应气候变化战略 }\end{array}$ & $\begin{array}{l}\text { The National Development and Reform } \\
\text { Commission (NDRC) }\end{array}$ & $\begin{array}{l}\text { 'establishment' } \\
\text { 'improvement' } \\
\text { 'wide-spread' } \\
\text { 'enhancement' } \\
\text { 'ecological civilisation' }\end{array}$ \\
\hline & $\begin{array}{l}\text { National Plan on Climate Change (2014-2020) } \\
\text { 国家应对气候变化规划 } \\
\text { (2014-2020 年) }\end{array}$ & NDRC & $\begin{array}{l}\text { 'crucial' } \\
\text { 'actively responding to' } \\
\text { 'ecological civilisation' } \\
\text { 'international obligation' } \\
\text { 'responsible powerful nation' }\end{array}$ \\
\hline & $\begin{array}{l}\text { Action Plan for Urban Adaptation to Climate Change } \\
\text { (2016) } \\
\text { 城市适应气候变化行动方案 }\end{array}$ & $\begin{array}{l}\text { NDRC } \\
\text { Ministry of Housing and Urban-Rural } \\
\text { Development (MOHURD) }\end{array}$ & $\begin{array}{l}\text { 'vital interests of the people' } \\
\text { 'actively promote' } \\
\text { 'ecological civilisation' } \\
\text { 'more comprehensive and } \\
\text { forward-thinking policies' }\end{array}$ \\
\hline $\begin{array}{l}\text { Institutional } \\
\text { reform }\end{array}$ & $\begin{array}{l}\text { Decision of the Central Committee of the Communist } \\
\text { Party of China on Some Major Issues Concerning } \\
\text { Comprehensively Deepening the Reform } \\
\text { (2014) } \\
\text { 中共中央关于全面深化改革若干重大问题的决定 }\end{array}$ & $\begin{array}{l}\text { The 18th Central Committee of the } \\
\text { Communist Party of China (CCCPC) }\end{array}$ & $\begin{array}{l}\text { 'accelerate ecological progress' } \\
\text { 'establish complete and } \\
\text { integrated institutions and } \\
\text { systems' 'reforming the } \\
\text { systems' } \\
\text { 'ecological civilisation' } \\
\text { 'powerful measure' } \\
\text { 'top priority of environmental } \\
\text { protection work' }\end{array}$ \\
\hline
\end{tabular}

Selected samples of plans and policies addressing climate change and health at national level in China. The table displays the names, policy-making institutions and natures of these plans and policies, and key words that reflect the institutional perception and framing of climate change impacts on health. 
the Strategy highlights human health as one of the seven important tasks to be implemented by 2020. This includes:

- establishing climate change-health monitoring, assessment, early warning systems;

- improving the control system of infectious diseases;

- wide spreading the knowledge and skills of health protection facing climate change, as well as

- enhancing health supervision and law enforcement.

The Strategy defined the goal to protect health from increasing risks of occurrence and spread of many diseases, especially temperature-sensitive illnesses and post-disaster infectious diseases. Climate change researchers also back the necessity of establishing early warning and monitoring systems (Du et al. 2013).

\section{The action plan on prevention and control of air pollution 2013}

This action plan is an outcome of the 7th National Conference on Environmental Protection in 2011. The conference framed decent environmental quality as a public good that governments ought to provide, which requires resolving major environmental problems that jeopardize human health and development. The action plan, thus, sets human health as both the entry point and fundamental interest, and has laid out ambitious, specific targets from the national level to reduce ambient air pollution and to improve air quality nationwide by the end of 2017. It aimed to reduce PM10 by at least 10 percent relative to 2013 levels across all urban areas. The most heavily polluted and most densely populated urban areas in the country: BeijingTianjin-Hebei, Pearl River Delta, and Yangtze River Delta, received specific targets to reduce PM2.5 by $25 \%, 20 \%$, and $15 \%$ respectively. For Beijing, the target was to reduce PM2.5 by 34\% from the 2013 level. In addition to differentiated targets for different regions, the plan also focused on these 10 areas of action:

(1) Emission reduction of multiple pollutants including those from transportation, industry, and catering, including prohibiting new coalfired plants in the three target regions and require existing coal plants to reduce emissions or be replaced with natural gas

(2) Adjustment and optimization of the industrial structure, e.g. reducing iron and steel making capacity in the industry

(3) Innovation in science and technology for cleaner production

(4) Adjustment of the energy structure and increase in clean energy supply, for example, increasing renewable energy generation
(5) Application of energy conservation and environmental protection indicators to industry, and optimization of industrial facility layout

(6) Regulation by market mechanisms and environmental economic policies, such as prices, taxes, investment and financing

(7) Improvement of the legal and regulatory systems and enhancement of execution, for example, stricter enforcement of emissions standards.

(8) Regional cooperation mechanisms for environmental governance, incentivizing local government officials by linking pollution reduction outcomes with promotions through environmental audits in their jurisdictions

(9) Establishment of monitoring and early warning systems

(10) Promote the private sector as well as civil forces to participate in environmental protection

\section{National environmental health action plan (2007-2015)}

The National Environmental Health Action Plan (2007-2015) was the first national guiding principle document addressing the environment-health nexus and calling for actions. It is coordinated by the Ministry of Health and sixteen other ministerial agencies. The Plan noted that environmental degradation, the destruction of ecological balance, and harm to human health have "increasingly become the key factors constraining economic growth and affecting the harmonious development of society. The Plan strives to solve major environmental problems that endanger the health of the people and to further promote sustainable socio-economic development. It has defined it as both a 'basic requirement and an important task' for establishing the 'people-oriented governance' and building a 'harmonious socialist society (State Council of China 2007, p. 3).' This Plan highlighted the significance of resolving major environmental health problems through environmental health assessments - namely, the impacts of climate change on human health and coping strategies. The effects of climate change on human health referred to in this Plan include the impacts of extreme weather and climate events such as heatwaves, storm floods, dust storms, droughts, floods, and other climate change-induced or intensified diseases. Besides, the Plan also emphasized the importance of establishing early warning systems, emergency response plans, related methods and technologies, and effectiveness evaluations of these interventions.

National plan on climate change (2014-2020) Several incidents prompted China's increasingly affirmative gesture on environmental and climate change governance. China overtook the U.S. and 
became the biggest $\mathrm{CO} 2$ emitter in 2007 and gained international exposure from hosting the International Olympic Games in 2008. Air pollution has become a genuine concern of citizens as more evidence surfaced, indicating negative health consequences. There is an evident change in the central government's political gesture towards the challenges of climate change impacts. As shown in the National Plan on Climate Change (2014-2020), climate change was deemed as 'crucial' in influencing the overall socio-economic development, the security of energy, food, ecological environment, and human health. Besides, the Plan frames 'actively responding to climate change' as both an inherent requirement for achieving Ecological Civilization, the country's overall environmental and development agenda, as well as a significant opportunity for transforming the current economic development model. The Plan further frames it as an 'international obligation' of the country as a 'responsible powerful nation.'

\section{Action plan for urban adaptation to climate change}

This Action Plan places a primary focus on the role of cities in climate change adaptation, as cities host a significant quantity of social and economic activities. As reviewed in the previous chapters, the urban population in Guangzhou is exposed to high risks of severe climate change impacts, mainly due to its high density. The Action Plan for Urban Adaptation to Climate Change (State Council of China 2016b) was cocarried out by the National Development and Reform Commission (NDRC) and the Ministry of Housing and Urban-Rural Development (MOHURD) in 2014. The Action Plan sets the stage that 'urban adaptation to climate change is about the vital interests of the people.' Besides, it supports cities to 'actively promote' climate change adaptation by addressing public health, among other aspects (depending on each city's specific climate change challenges), in their pilot work programs. The Plan emphasizes that cities take action to adapt to climate change is an essential contribution to achieving Ecological Civilisation - the country's sustainable environmental and socio-economic development agenda. The Action Plan requires cities to make 'more comprehensive and forward-thinking' policies for climate change adaptation. For Guangzhou, this implies making policies that incorporate updated scientific evidence to manage the impacts of storms and floods more effectively.

\section{The decision of the CCCPC on some major issues} concerning comprehensively deepening the reform The centralized government administration dominates the current governance system in China, and its primary long-term goal is to support socioeconomic development. Over the last decades, achievements in the socio-economic development in China is evident, while environmental externalities and health risks emerged as a new governance challenge. There is an increasing need to reform the institutions of environmental and health governance in order to address these environmental externalities more efficiently. The 18th Central Committee of the Communist Party of China (CCCPC) responded to this need with high political determination. In 2014, the Committee passed the Decision of the CCCPC on Some Major Issues Concerning Comprehensively Deepening the Reform (Supreme People's Court of China 2015). The decision urged all sub-ordinary governments to 'accelerate ecological progress' by establishing 'complete and integrated institutions and systems' to protect the ecological environment. The former inaugural Minister of Environmental Protection Zhou Shengxian underlined the importance of reforming the environmental protection management system. He refers the reform as a powerful measure to solve 'outstanding environmental problems that damage the health of the people,' and that solving the problem of atmospheric, water and soil pollution which damages the health of the people is a 'top priority' of environmental protection work (Zhou/State Council of China 2014).

\section{Healthy China 2030 plan}

The Central Committee of the Communist Party endorsed the Healthy China 2030 Plan in 2015, which entered in effect in 2016. This is China's first national medium- to long-term action plan strategically focusing on health. It aims to promote healthy lifestyles, improve health services and the health industry. Besides, the Plan outlines the vision of a sustainable health system to provide essential health services to every citizen by 2020 . The Plan defines health as a 'basic condition for socio-economic development.' It states that improvement in national health governance is a 'proactive contribution to global health governance and fulfilment to the commitment of 2030 Sustainable Development Agenda' (State Council of China 2016a). To achieve these aims and visions, the Healthy China 2030 Plan puts forward five strategies: popularizing a healthy life, optimizing the health service, improving health protection, building a healthy environment, and developing a healthy industry. In actionable terms, the Plan seeks to resonate with the advocacy of the WHO: 'Health in All Policies' (HiAP) and to reach the primary health indicators of high-income countries by 2030 .

The national action plans and decisions introduced above recognize human health as a highly relevant factor in influencing the country's socio-economic performance and target health improvement with a high political will. Nevertheless, human health is being listed, among others, only in the last places in 
the framing of subject significance facing climate change. Besides, since launching the National Strategy for Climate Change Adaptation in 2013 onwards, addressing the nexus between climate change and human health nexus has been defined as essential for achieving Ecological Civilization. Ecological Civilization is China's national paradigm, or philosophy, for environmental governance or sustainable development. The concept is framed to distinguish from the previous philosophies of development that emerged since the 1980s, such as Spiritual Civilization, Material Civilization, and Political Civilization. Is it also framed as the opposite of the anthropological worldview advanced by the Western modernization process (Geall and Ely 2018). The concept of Ecological Civilisation is increasingly emphasized and interpreted in the major development plans and policies analysed. We conclude from these institutional narrative examples that, narrating climate change impacts and health at the national level in China, including the targeting and framing, is primarily a demonstration of political will and determination from a central and macro perspective, and they set the fundamental principle as well as directions for action.

\section{Institutional narratives of climate change impacts and health at the local level}

The Program for Addressing Climate Change of Guangdong Province (广东省应对气候变化方案) launched in 2011 was a direct response of the provincial government of Guangdong to The National Environmental Health Action Plan 2007-2015. To a great extent, the Program has guided the institutional narratives of climate change impacts and health in Guangzhou. The Program builds on the overall situation of global and regional warming, and the implications it has on human health and economic development in the Cantonese region. Particularly, it openly recognizes the challenges to address climate change in this region, including the conflict between prioritizing economic development (consumption of energy especially fossil fuels) and reducing emissions, and disaster-prone natural condition that this region possesses. Accordingly, the Program sets out key tasks for both mitigation and adaptation. Reducing impacts on human health is emphasized in the adaptation tasks, namely, through a) monitoring real-time weather changes, the incidence of extreme weather events, and the incidence of respiratory diseases, and b) improving the emergency response mechanisms based on health risk assessments.

Having had a comprehensive narrative of climate change impacts on health and action guidance from the provincial level such as in The Program for Addressing Climate Change of Guangdong Province 2011, local meteorological services are still necessary as they are vital references for understanding changes in the local climate and impacts at the local level. In addition to keeping a track record of and publishing weather data, the meteorological service institutions serve an essential function in narrating the data to decision-makers and the broader public. In 2013, the Guangdong Meteorological Service published the Guangdong Province Climate Change Monitoring Bulletin 2013 (Guangdong Meteorological Service 2014), systematically explaining the climatic changes of the last five decades of this region for the first time, including changes in average temperature, precipitation, haze and sea level, all of which possess a 'significant upward trend'. The Bulletin recognized these changes as the consequences of global climate change.

Such data is further employed in research among major provincial and municipal health institutions to enhance the understanding of climate change impacts on public health locally. Guangdong Provincial Institute of Public Health (GPIPH) is one of such major institutions. To a large extent, narrating climate change impacts and health among such institutions is also a way of knowledge co-creation and institutional capacity building. For instance, several seminars hosted by the GPIPH and participated by fellow health institutions and university research groups exchanged findings and discussions on the 'nexus between climate change and public health,' and 'communication strategies' of climate change-related health risks (Guangdong Provincial Institute of Public Health 2013a, 2013b). Guangzhou also joined the C40 Climate Leadership Group in 2015 - a positive gesture aligning the Guangzhou government's goal with that of the C40's fellow cities - to reduce greenhouse gas emissions and reduce the risk of climate change, while improving the health and well-being of urban residents and increasing economic opportunities (Municipal Government of Guangzhou 2015). Although, despite well-aimed, initiatives or policies from this city alliance addressing the climate changehealth problem of Guangzhou are still rare.

The 13th Five-Year Plan (FYP) To Cope with Climate Change in Guangdong Province (China Climate Change Info-Net 2017) is the most recent example of institutional narrative of climate change impacts on health launched by the Guangdong Provincial DRC. The 13th FYP recognizes the impacts of climate change on health as 'realistic and extensive' and are 'increasingly threatening human health' due to the intensifying phenomena of urban heat-island effects and heatwaves. These impacts cause heat strokes and increase the risks of infectious diseases. The 13th FYP also confirmed the ongoing need to 'assess vulnerable areas and groups' to climate change, to 'establish a disease prevention and control mechanism,' and to 'enhance citizens' awareness' towards climate change impacts on human health. 
Finally, we examined the text of a major scientific research project on 'climate risk assessment and climate alert for dengue under climate change.' Institutionally, the China Meteorological Administration and the GPIPH support this project. The project evaluated the impacts of climate change on the prevalence of dengue fever in South China and projected the potential changes of dengue fever in different regions in the future, taking into consideration various greenhouse gas concentration scenarios, or Representative Concentration Pathways (RCPs) (Xiang et al. 2017).

In these plans, policies, and information produced by provincial and municipal institutions listed in Table 3, we found that institutions at this level focus on enhancing the capacity and ability to understand the impacts of climate change on health, through making active use of the weather data and co-learning opportunities and projects.

We identified several problems from the institutional narrative analysis regarding urban health governance in Guangzhou. First, the frequent emphasis of building early warning and monitoring systems and enhancing public awareness indicates that institutional narratives stress primarily on the technological and educational means for climate change-health governance. However, the technological and educational means might not be sufficient for addressing climate change adaptation and urban health problems, as both of which are increasingly referred by scholars as 'wicked problems' due to their high scientific and economic complexity with radical uncertainties as previously described. Technological and educational measures to address the complex climate-health nexus are good starting points. However, policymakers need to link them together in order to build an overall integrated governance strategy across sectors in which technology and education are part of other interlinked social, ecological urban health determinants (Periyakoil 2007).

Second, urban health governance in Guangzhou, as narrated institutionally, relies primarily on singledepartment and regulative measures. We suggest this could be due to the characteristic of the centralized and top-down planning tradition in China as political scholars (e.g. Fukuyama 2016) view. Regulative measures aligned with central level objectives and implemented by single departments often have the advantage of being delivered efficiently; however, relying primarily on regulative measures means that local governments might miss the support of the private sector and communities. Scholars consider these non-regulative mechanisms necessary to tackle severe social problems and achieve beneficial community outcomes (Bryson et al. 2006, Frumkin et al. 2008, Adeleye and Ofili 2010).

Lastly, in the above institutional analysis, we did not find narratives that specifically address the role of financial assessments in health governance actions.
Financial resources are critical for the success of policy interventions and actions on climate change. On the other hand, we find that policy-making institutions at the local level recognize the scientific knowledge on climate change and health nexus well and frequently refer to the risks of climate change impacts on health well in various policy documents. Political rhetoric reflects scientific knowledge well. Here, the contrast between the emphasis on scientific evidence and the lack of emphasis on financial assessments of actions presents a gap between knowledge and action, or a gap between knowledge and financially sustainable action. We suggest that this could be a sign of lacking a coherent or systemic approach to the climate change-health nexus. To confirm this possible explanation, in the next section, we compare the institutional objectives and examine the effectiveness of actions on climate change as a means of health governance both at the national and local levels.

\section{Institutional objectives, effectiveness and impacts}

\section{Institutional objectives from national and local \\ levels}

Comparing the objectives of both the national and local level policies listed above, we found that: at the national level, there is a much higher awareness of the climate change impacts on health and the need for action; whereas at the local level, policy objectives have mainly targeted on public education of the basic facts of climate change, primarily based on the weather data analysis and learning.

This result showcases that at the local level, there is to a certain extent a lack of knowledge of climate change impacts on health. The institutions at the national level narrate climate change impacts more maturely with greater emphasis compared to the institutions at the local level. In addition, despite positive political will and objectives to protect health from climate change impacts both at the national and local levels, the local level governments still prioritize socio-economic development over urban health, for example, as revealed in the provincial master plan for climate change adaptation.

\section{Actual effectiveness of climate and health actions}

Despite that institutional narratives at the national and local levels differ to a certain degree on the importance of protecting health under climate change, actions were taken to reduce air pollution, enforce stricter emissions standards, and to improve the energy structure. Nationally, coal mines were shut down. In 2017, Shanxi province, which was - and still is - China's largest coal producer, shut down 27 coal mines. The same year saw improved transparency in government reporting of air quality statistics - over 5000 monitoring stations were built as a nationwide network of air pollution monitors in which the data is publicly available (EPIC n.d.). 
Table 3. Key plans and policies addressing climate change and health at provincial and municipal level in Guangzhou.

\begin{tabular}{|c|c|c|c|}
\hline Functions & Example & Policymakers/institutions & Key words \\
\hline $\begin{array}{l}\text { Climate change } \\
\text { information } \\
\text { provision }\end{array}$ & $\begin{array}{l}\text { Guangdong Province Climate Change } \\
\text { Monitoring Bulletin } 2013 \\
\text { 2013年广东省气候变化监测公报 }\end{array}$ & Guangdong Meteorological Service & 'significant upward trend' \\
\hline \multirow[t]{3}{*}{$\begin{array}{l}\text { Institutional } \\
\text { capacity } \\
\text { building }\end{array}$} & $\begin{array}{l}\text { International forum on climate change and } \\
\text { public health } \\
\text { 气候变化与公共卫生国际论坛 }\end{array}$ & $\begin{array}{l}\text { Guangdong Provincial Institute of Public } \\
\text { Health (GPIPH) } \\
\text { Provincial Center for Climate (PCC) } \\
\text { Guangdong Provincial Institute for Health } \\
\text { Inspection }\end{array}$ & $\begin{array}{l}\text { 'climate change-public health } \\
\text { nexus' }\end{array}$ \\
\hline & $\begin{array}{l}\text { Seminar on risk communications of high } \\
\text { temperature and heatwaves } \\
\text { 高温热浪风险沟通材料研讨会 }\end{array}$ & $\begin{array}{l}\text { GPIPH, Universities, PCC } \\
\text { Provincial Institute for Occupational } \\
\text { Disease Prevention and Treatment of } \\
\text { Guangdong } \\
\text { GPCDCP } \\
\text { Heatwave vulnerable groups }\end{array}$ & 'rick communication strategies' \\
\hline & $\begin{array}{l}\text { Guangzhou joined C40 Climate Leadership } \\
\text { Group } \\
\text { (2015) } \\
\text { 广州加入C40城市气候领导联盟 }\end{array}$ & $\begin{array}{l}\text { Foreign Affairs Office of Guangzhou } \\
\text { Municipal Government of Guangzhou } \\
\text { Municipal DRC of Guangzhou }\end{array}$ & $\begin{array}{l}\text { 'climate leadership' } \\
\text { 'improving the health and well- } \\
\text { being of urban residents' }\end{array}$ \\
\hline $\begin{array}{l}\text { Major research } \\
\text { project }\end{array}$ & $\begin{array}{l}\text { Climate risk assessment and climate alert for } \\
\text { Dengue under climate change } \\
\text { 中国气象局气候变化专项 '气候变化 } \\
\text { 背景下登革热气候风险评估和气候预 } \\
\text { 警' }\end{array}$ & $\begin{array}{l}\text { China Meteorological Administration } \\
\text { GPIPH }\end{array}$ & 'climate risk assessment' \\
\hline \multirow[t]{4}{*}{ Action plan } & $\begin{array}{l}\text { The Program for Addressing Climate Change } \\
\text { of Guangdong Province } \\
2011 \\
\text { 广东省应对气候变化方案 }\end{array}$ & Provincial government of Guangdong & $\begin{array}{l}\text { 'accelerate economic structural } \\
\text { transformation' } \\
\text { 'optimize energy structure' } \\
\text { 'increase nature-based carbon } \\
\text { sequestration' } \\
\text { 'improve monitoring system and } \\
\text { emergency response' }\end{array}$ \\
\hline & $\begin{array}{l}\text { The 13th Five-Year Plan (FYP) To Cope with } \\
\text { Climate Change in Guangdong Province } \\
2017 \\
\text { 广东省应对气候变化“十三五“规划 }\end{array}$ & Provincial DRC of Guangdong & $\begin{array}{l}\text { 'realistic and extensive impact' } \\
\text { 'increasingly threatening human } \\
\text { health' } \\
\text { 'assessment' } \\
\text { 'establish monitoring and } \\
\text { emergency response system' }\end{array}$ \\
\hline & $\begin{array}{l}\text { The Special Plan for Sponge City } \\
\text { Construction in Guangzhou } 2016 \\
\text { 广州市海绵城市专项规划 2016-2030 }\end{array}$ & $\begin{array}{l}\text { Guangzhou Land Resources and Urban } \\
\text { Planning Committee }\end{array}$ & $\begin{array}{l}\text { 'resolve urban inundation, } \\
\text { blackened and polluted water } \\
\text { bodies' } \\
\text { 'promote sustainable } \\
\text { development' }\end{array}$ \\
\hline & $\begin{array}{l}\text { The 1st Work Plan of Carbon Emission Quota } \\
\text { Allocation of Guangdong Province } 2013 \\
\text { 广东省碳排放权配额首次分配及工作 } \\
\text { 方案 }\end{array}$ & Provincial DRC of Guangdong & $\begin{array}{l}\text { 'test the management and trading } \\
\text { scheme of carbon emission } \\
\text { rights' }\end{array}$ \\
\hline
\end{tabular}

Selected samples of plans and policies addressing climate change and health at the provincial and municipal levels in Guangzhou. The table displays the names, policy-making institutions, and natures of these plans and policies, and keywords that reflect the institutional perception and framing of climate change impacts on health.

Locally, the Guangzhou municipal government mainly worked on reducing air pollution in the transportation sector, reducing carbon emissions by establishing a carbon trading scheme, and capacity building by making climate-specific work plans and by training government officials. The Guangzhou Bus Rapid Transit system (BRT), established in 2010, is a model for affordable, low-carbon high-volume public transit. It was considered effective in climate mitigation and was chosen by the United Nations' climate change program in 2012 as one of the nine Lighthouse Activities in climate action (UNFCCC 2012). The buses employed in this BRT system include (oil and gas) hybrids and electric ones. By 2018, the city's public transportation system is equipped with more than 11,000 electric buses and more than 4,000 electric vehicle charging piles. For this work, Guangzhou was awarded in the category of Green Technologies during the 2019 C40 World Mayors Summit (Xinhua 2019).
On carbon emission reduction, the Guangdong provincial Development and Reform Committee (GDDRC) launched a carbon trade scheme in 2013 with 1) defined carbon emission quotas for enterprises with large energy consumption, as well as with 2) a trade mechanism for emission rights. The scheme initially targeted enterprises primarily from four industries - electricity, steel, petroleum, and cement. By 2018, major enterprises from the paper and the aviation industries were also listed in the carbon trade scheme (GDDRC 2018). In 2015, the GDDRC established the Guangdong Research Center for Climate Change (广东省应对气候变化研究中心). This research centre conducts research, policy planning, expert knowledge support, and training government officials on topics of climate change impacts. The 13th Five-Year Plan (FYP) To Cope with Climate Change in Guangdong Province introduced above, for example, is an endeavour of this research centre. 


\section{Assessing policy impacts based on institutional objectives and effectiveness}

In this subsection, we discuss the potential impacts of the aforementioned national and local policies on climate change and health governance, based on the institutional narrative analysis in Section 5.1 and 5.2, plus the institutional objective and effectiveness analysis in the first two parts of Section 5.3. We consider four main aspects of policy impacts: the relevant stakeholders, the resources required, the intended and spill over effects, and finally, the lifespan of these policies.

First, both national and local institutional narratives acknowledge the impacts of climate change on the health of the people and recognize primarily the role of sub-level governmental institutions in actions. The institutional narratives also recognize the role of the private sector in contributing to health governance, but mainly through conformance to governmental regulations. We confirm the presence of such regulatory relationship between local level governments and the private sector in the review of actions and their effectiveness.

Second, as it is reviewed in Subsection 5.2, even though financial resources are critical for the success of policy interventions and actions on climate change, its role has rarely been addressed in the institutional narratives. Despite that it appears that the institutional narratives analysed above have established credibility judging from some of the evidence of policy effectiveness; due to the lack of emphasis on financial assessments of actions, we are not be able to ascertain the longevity or implementability of the policies and plans introduced above.

Third, these policies and plans seem to have been displaying the intended effects, judging from some of the evidence of policy effectiveness. However, these institutional narratives have only emphasized the roles of sub-level governments and the private sector in regulatory terms and have not sufficiently addressed the role of citizens as individual actors in climate actions and health preventions. We therefore do not exclude the possibility of positive or negative spill over effects on the citizens.

Lastly, we consider the lifespan of these policies and plans to be highly dependent on the political will of enforcement, as by far we find the institutional narratives are of a conventional top-down gesture. Again, due to the insufficient incorporation of the citizen actors, we are unable to determine to what extent these narratives are effective in informing citizens the impacts of climate change on health and in stimulating actions. Without a clear account on the degree of citizen participation or the financial input, the lifespan of these policies and plans are highly dependent on the political will of the level of institutions who narrate them.

\section{Improving institutional narratives of climate-health nexus with systems thinking}

Through the institutional narrative analysis and the assessment of the objective, effectiveness, and impacts conducted above, we argue that local governments still need to develop a real integrated vision or strategy for climate change risk assessment and health governance mechanisms. Failure to cope with complex social and infrastructural interactions of connected and interdependent agents within the natural and built environment generated urban health problems. Grappling such complexity and improving urban health resilience in a compact and fast-growing city like Guangzhou and facing 'wicked' climate change problems requires framing the climate change-health nexus more prominently and comprehensively. Systems thinking for urban health is based on complex systems theory by viewing cities are complex adaptive systems. As a genre of intellectual efforts, it recognizes the multiple values of urban system goods and services (Elmqvist et al. 2019), which, because of their different nature, require diverse and specialized approaches in management and action. Scholars have long propagated systems thinking for determining etiological factors in complex environments. In complex environments, feedback, interactions, and interdependencies occur over time, both through computational means and as a holistic approach in general (Trochim et al. 2006, Frumkin and McMichael 2008, Williams et al. 2010, EEA 2013). Therefore, in addition to addressing the complex climate change health nexus by technological and educational fixes, research and development could contribute to a better understanding of the climate change - health nexus by applying systems thinking to urban health (Gatzweiler et al. 2016).

Systems thinking enables addressing the nexus issues identified from the example of institutional narratives of climate change impacts for health governance in Guangzhou. First, enhancing resilience means better preparing the society under climate change, and one way to do so is by equipping individual citizens with the scientific knowledge of the climate change - health nexus through raising awareness and education. Applying systems thinking requires to go beyond getting to know the direct climate change impacts, such as heatwave-sensitive deaths, but to link multiple social goods and services into the context, e.g. how increasing waste heat from automobiles, air conditioning, industry and decreasing amount of vegetation boost the urban heat island effect at the local scale and warming at the global scale, further exacerbating the health consequences of heatwaves, as their frequency and intensity increase. By accounting more systemically for the interactions between individual activities and the environment, we then need to 
institutionalize them by, for instance, laws, regulations, and incentives mechanisms, for actual behavioural change to occur (Brondízio et al. 2012) and urban health to improve.

Besides, systems thinking can dissipate the dominance of administrative order by tapping into the functions of market instruments, and by encouraging other actors - civil society and entrepreneur - to participate and develop cross-sector collaborations, for three reasons. One, regardless of the political forms of organization, in a systems perspective, all actors play a role, interact, and exchange goods and services in an urban system that create impacts on health. Seeking only the administrative means, or, the 'rule of the game,' will be incomplete without also examining who plays it and how it is being played. Second, civil society and business are essential actors in the urban social system; they, therefore, actively participate in their practices to improve health under climate change. For instance, an entrepreneur contribution could accelerate the technology needed for early warning and monitoring systems through competition and innovation; civil actors could devote to building a local health monitoring and contingency response network; local climate action groups could engage in informing their communities about the health effects of climate change and local adaptation measures. Non-governmental actors, therefore, could enrich the narratives of climate change impacts for health through adding community's health vulnerability self-assessments, in addition to the data and modelling of scientific institutions and the top-down and standardized advice from government institutions. Third, while being the tradition and necessary, and despite the ability to deliver policies with predictability, consistency, and repeatability, the top-down government structure is increasingly failing to deliver economic efficiency as social actors and their preferences continue to diversify and health problems remain wicked or deteriorate, and related policies or public services fall short to respond to these changes (Wilson 1974, Ostrom and Allen 2007, Wang 2015). Such is the case of urban health in Guangzhou.

\section{Conclusion: systems thinking needed for climate change-health governance in Guangzhou}

In this paper, we started by recounting the impacts of climate change, namely intensified heat waves, air pollution, and typhoons, to the health of urban residents in Guangzhou, which are significant plus high scientific uncertainties and merit inquiries for effective solutions. We then constructed a theoretical framework to build the ground of possibilities for the institutional narrative analysis. Through the institutional narrative analysis focusing on the plans, policies, and relevant activities made or conducted by government institutions, we identified significant streams in the institutional narrative of climate change impacts for health, including the conventionality of means, heavy reliance on the administrative order, and lack of civil actor participation. We identified a knowledge-action gap resulting from (abundant) national policies formulated on sound scientific evidence and addressing urgent climate change and health nexus problems, while local understanding, experiences, and means for addressing the complex climate-health challenges remain limited. For resolving these problems, we proposed systems thinking as necessary methodological guidance to make the climate change-health nexus more prominent, comprehensible, and manageable, hence, to enhance urban health governance in Guangzhou.

To conclude, institutional narratives in China are inevitably subjected to its top-down governance tradition with centralized power. These narratives are based on state-of-the-art scientific knowledge and formulated by the country's intellectual elite. Theoretically, such a system has the advantage of responding to change along a clear line of command. However, the nature of climate change health nexus problems is intrinsically complex and challenges the effectiveness of a top-down governance approach. Furthermore, the speed of social, economic, and environmental changes is increasingly outpacing the speed of government planning and adaptation, making such a form of governance insufficient to manage complex environmental conditions such as climate change. Between scientific findings of climate change impacts on health, existing plans and policies, and the residents' preparedness, such vertical administration structure does not encourage inter-departmental or cross-sector collaborations. In addition, a top-down approach cannot guarantee that local governments will fully take on a mission defined by the central government, as local governments also need to balance the need for socio-economic development. This can be seen clearly from the fact that policies and plans at the local level are lack of the financial resource assessments necessary for implementation. To improve governance of urban health facing climate change in Guangzhou, institutions would need first to perceive and narrate climate change risks comprehensively and comprehensible, in order to make risk-informed demographically targeted policies. The establishment of a multi-sectoral cooperation mechanism could benefit urban health governance, by encouraging entrepreneur innovation for building accurate early warning and monitoring systems, and by engaging civil society or communities for building self-organized response networks and bottom-up feedback, hence improving their 
preparedness. This vision of change can be driven by systems thinking and can help in implementing the 'Healthy China 2030' initiative.

\section{Notes}

1. https://en.oxforddictionaries.com/definition/ narrative.

2. https://www.merriam-webster.com/dictionary/ narrative.

\section{Geolocation information}

The geographical location mentioned in this research is Guangzhou city, capital of Guangdong Province, southeast China.

\section{Acknowledgements}

This research as part of the author's PhD thesis research project has been financially supported by the Portuguese National Foundation of Sciences and Technology (FCT) under Grant number PD/BD/128209/2016 and intellectually supported by the author's two supervisors: Professor Franz Gatzweiler, the Executive Director of the International Science Council Program "Urban Health and Wellbeing" (UHWB) hosted by the Institute of Urban Environment Chinese Academy of Sciences, and Professor Olivia Bina, faculty member of the PhD program in Climate Change and Sustainable Development Policies and Principal Researcher at the Institute of Social Sciences - University of Lisbon.

\section{Disclosure statement}

No potential conflict of interest was reported by the author.

\section{Funding}

This work was supported by The Foundation for Science and Technology (Portuguese: Fundação para a Ciência e a Tecnologia, FCT) [PD/BD/108209/2016].

\section{Notes on contributor}

Jieling Liu is a $\mathrm{PhD}$ candidate in Climate Change and Sustainable Development Policies at Institute of Social Sciences - University of Lisbon. She has an academic background in Political Sciences and Journalism. Jieling is also junior researcher for 'Urban Health and Wellbeing: a Systems Approach' - the interdisciplinary program of the International Science Council. Jieling's thesis examines the planning and governance of urban green as commonpool resources for climate change adaptation and health and wellbeing, in the context of rapid socio-economic urban development in China, with case studies drawn from Guangzhou. Her thesis applies Ostrom's Institutional Analysis and Development Framework for analysis.

\section{ORCID}

Jieling Liu (D) http://orcid.org/0000-0002-7930-9099

\section{References}

Adeleye, O.A. and Ofili, A.N., 2010. Strengthening intersectoral collaboration for primary health care in developing countries: can the health sector play broader roles? Journal of environmental and public health, Article ID 272896, 6. doi:10.1155/2010/272896.

Ashby, R., 1984. The viable system model: its provenance, development, methodology and pathology. Journal of the operational research society, 35 (1), 7-25. doi:10.1057/ jors. 1984.2

Barry, D. and Elmes, M., 1997. Strategy retold: toward a narrative view of strategic discourse. Academy of management review, 22 (2), 429-452. doi:10.5465/ amr.1997.9707154065

Berry, H.L., Bowen, K., and Kjellstrom, T., 2010. Climate change and mental health: a causal pathways framework. International journal of public health, 55 (2), 123-132. doi:10.1007/s00038-009-0112-0

Best, A., National Cancer Institute, 2007. Greater than the sum: systems thinking in tobacco control. Bethesda, MD: National Cancer Institute, U.S. Dept. of Health and Human Services, National Institutes of Health.

BMC Springer Nature, n.d. China-UK global health support programme [online]. Available from: https://www.bio medcentral.com/collections/ghsp

Brondízio, E., et al., 2012. Chapter 4 - Socio-cultural context of ecosystem and biodiversity valuation. In: P. Kumar, ed. The economics of ecosystems and biodiversity: ecological and economic foundations. London: Earthscan.

Bryson, J.M., Crosby, B.C., and Stone, M.M., 2006. The design and implementation of cross-sector collaborations: propositions from the literature. Public administration review, 66 (1), 44-55. doi:10.1111/j.15406210.2006.00665.x

China Daily, 2007. Ecological civilization. Available from: http://www.chinadaily.com.cn/hqzg/2007-10/16/con tent_6180418.htm

Chughtai, S. and Blanchet, K., 2016. Systems thinking in public health: a bibliographic contribution to a meta-narrative review. Health policy and planning, 1-10. doi:10.1093/heapol/czw159

Doelle, M., 2010. The legacy of the climate talks in Copenhagen: hopenhagen or brokenhagen? Carbon and climate law review, 4 (1), 86-100. doi:10.21552/CCLR/ 2010/1/132

Du, Y.D., et al., 2013. Impacts of climate change on human health and adaptation strategies in South China. Advances in climate change research, 4 (4), 208-214. doi:10.3724/SP.J.1248.2013.208

Elmqvist, T., et al., 2019. Resilience management for healthy cities in a changing climate. In: M. Marselle, et al., eds. Biodiversity and health in the face of climate change. Cham: Springer International Publishing, 411-424.

European Environment Agency (EEA), 2013. Reducing the $€ 45$ billion health cost of air pollution from lorries. Press Release, February. Available from: https://www.eea. europa.eu/media/newsreleases/reducing-the-20ac-45billion

Ewick, P. and Silbey, S.S., 1995. Subversive stories and hegemonic tales: toward a sociology of narrative. Law \& society review, 29 (2), 198-226. doi:10.2307/3054010

Fritze, J.C., et al., 2008. Hope, despair and transformation: climate change and the promotion of mental health and wellbeing. International journal of mental health systems, 2 (13). Olicensee BioMed Central Ltd. doi:10.1186/17524458-2-13 
Frumkin, H., et al., 2008. Climate change: the public health response. American journal of public health, 98 (3), 435-445. doi:10.2105/AJPH.2007.119362

Frumkin, H. and McMichael, A.J., 2008. Climate change and public health. Thinking, communicating, acting. American journal of preventive medicine, 35 (5), 403-410. PMID: 18929964. doi:10.1016/j. amepre.2008.08.019

Fukuyama, F., 2016. Reflections on Chinese governance. Journal of Chinese governance, 1 (3), 379-391. doi:10.1080/23812346.2016.1212522

Gatzweiler, F., et al., 2016. Advancing health and wellbeing in the changing urban environment: implementing a systems approach. Springer, Zhejiang University Press. ISBN: 978-7-308-16445-0.

Geall, S. and Ely, A., 2018. Narratives and pathways towards an ecological civilisation in contemporary China. China quarterly, 236, 1175-1196. doi:10.1017/ S0305741018001315

Gerrig, R.J., 1993. Experiencing narrative worlds: on the psychological activities of reading. New Haven, CT: Yale University Press.

Gibbon, J.F. and Mensah, K.O., 2012. Climate change as a wicked problem: an evaluation of the institutional context for rural water management in Ghana. SAGE Open. doi:10.1177/2158244012448487

Grundmann, R., 2016. Climate change as a wicked social problem. Nature geoscience, 9, 562-563. doi:10.1038/ ngeo 2780

Gu, C., and Wu, F., 2010. Urbanization in China: processes and policies. ChinaReview,10(1), 1-9. Available from http://www.jstor.org/stable/23462240

Guangdong Meteorological Service, 2014. Provincial meteorological service issued the first annual climate change monitoring bulletin (in Chinese: 省气象局首发 年度气候变化监测公报) [online]. June. Available from: http://gd.cma.gov.cn/zwgk/zwyw/gzdt/201406/ t20140603_65820.html

Guangdong Provincial Development and Reform Committee (GDDRC), 2018. Plan of carbon emission quota allocation and implementation of Guangdong Province 2018 (in Chinese: 广东省2018年度碳排放配额 分配实施方案). Available from: http://cnemission.com/ article/zcfg/gdszcwj/201812/20181200001573.shtml

Guangdong Provincial Institute of Public Health, 2013a. "International forum on climate change and public health" held at GDIPH (in Chinese: “气候变化与公共卫生国际 论坛” 在我中心召开) [online]. Available from: http:// www.gdiph.org.cn/ggw syjy/kydt/201403/ 2874b53165d548ad8e7b60345746e8b5.shtml

Guangdong Provincial Institute of Public Health. 2013b. GDIPH holds seminar on risk communications of high temperature and heatwaves (in Chinese: 我中心举办高 温热浪风险沟通材料研讨会) [online]. Available from: http://www.cdcp.org.cn/ggwsyjy/zhyw/201404/ 181b65344fb34fb3b49f6cd21d87474a.shtml

Hancock, T., and Duhl, L., 1988. Healthy Cities project: a guide to assessing Healthy Cities. Copenhagen: FADL Publishers. WHO.

Hannigan, B. and Coffey, M., 2011. Where the wicked problems are: the case of mental health. Health policy (Amsterdam, Netherlands), 101 (3), 220-227. doi:10.1016/j.healthpol.2010.11.002

Horn, R.E. and Weber, R.P., 2007. New tools for resolving wicked problems: mess mapping and resolution mapping processes. San Francisco, CA: Copyright (c) 2007 MacroVU(r), Inc. and Strategy Kinetics, LLC.
Ingram, M., Ingram, H., and Lejano, R., 2015. Environmental action in the anthropocene: the power of narrative-networks. Journal of environmental policy \& planning, 21 (5), 492-503. doi:10.1080/1523908X.2015.1113513

Landrigan, P.J., et al., 2018. The lancet commission on pollution and health. The lancet commissions, 391 (10119), 462-512. doi:10.1016/S0140-6736(17)32345-0

Lefsrud, L. and Jennings, P.D., 2013. Being entrepreneurial in your storytelling: an institutional tale [online]. Ross School of Business Paper No. 1207. Available from: https://ssrn.com/abstract $=2340100$

Liang, N., 2014. Alert! heat waves are silent health killers (in Chinese: 警惕! 高温热浪是沉默的健康杀手) [online]. Guangdong Provincial Center for Disease Control and Prevention. Available from: http://cdcp.gd.gov.cn/ $\mathrm{mtbdlist/content/post \_ 1108120.html}$

McBeth, M., Jones, M., and Shanahan, E., 2014. The narrative policy framework. In: P.A. Sabatier and C.M. Weible, eds. Theories of the policy process. Boulder, CO: Westview Press, 225-266.

Medard, M. and Geheb, K., 2001. Fisheries co-management in the tanzanian sector of lake victoria. Mwanza, Tanzania: Tanzania Fisheries Research Institute.

Meehl, G.A. and Tebaldi, C., 2004. More intense, more frequent, and longer lasting heat waves in the $21 \mathrm{st}$ century. Science, 305 (5686), 994-997. doi:10.1126/ science. 1098704

Mora, C., et al. 2017. Global risk of deadly heat. Nature climate change, 7 (7), 501-506. doi:10.1038/nclimate3322

Municipal Government of Guangzhou, 2015. Guangzhou officially joins C40 Urban Climate Leadership Alliance (in Chinese: 广州市正式加入C40城市气候领导联盟) [online]. September. Available from: http://www.gzfao. gov.cn/gzfao/csdbhz/201509/ca742199a 1 c f4aa980939935b826c77b.shtml

Ostrom, L., 2005. Understanding institutional diversity. Copyright by Princeton University Press. ISBN-13: 9780-691-12207-6.

Ostrom, V. and Allen, B., 2007. The intellectual crisis in American public administration. Tuscaloosa: The University of Alabama Press. Project MUSE.

Patterson, J.J. and Beunen, R., 2019. Institutional work in environmental governance. Journal of environmental planning and management, 62 (1), 1-11. doi:10.1080/ 09640568.2018.1538328

Periyakoil, V.S., 2007. Taming wicked problems in modern health care systems. Journal of palliative medicine, 10 (3), 658-659. (c) Mary Ann Liebert, Inc. doi:10.1089/ jpm.2007.9955

Provincial Government of Guangdong, 2011. The program for addressing climate change of Guangdong Province (in Chinese: 广东省应对气候变化方案). Government document number: [2011] No. 5.

State Council of China, 2007. Notice on issuing the national environment and health action plan (in Chinese: 关于印 发《国家环境与健康行动计划》的通知) [online]. November. Available from: http://www.gov.cn/zwgk/ 2007-11/16/content_807439.htm

State Council of China, 2013. National strategy for climate change adaptation (in Chinese: 国家适应气候变化战略) [online]. November. Available from: https://www.gov.cn/ gzdt/att/att/site1/20131209/001e3741a2cc140f6a8701.pdf State Council of China, 2014-2018. National Disaster Reduction Center of the Ministry of Civil Affairs released information about the basic situation of natural disasters nationwide 2013-2017 [online]. Available from: http:// www.gov.cn/gzdt/2014-01/04/content_2559933.htm, 
http://www.gov.cn/xinwen/2015-01/05/content 2800233.htm, http://www.gov.cn/xinwen/2016-01/11/ content_5032082.htm, http://news.cctv.com/2017/01/13/ ARTI42ph3AHW28QuVz0tmcgT170113.shtml, http:// www.gov.cn/xinwen/2018-02/01/content_5262947.htm

State Council of China, 2016a. State Council issued the "Outline of the Healthy China 2030 Plan. (in Chinese: 中 共中央国务院印发《“健康中国2030” 规划纲要》)

[online]. October. Available from: http://www.gov.cn/ zhengce/2016-10/25/content_5124174.htm

State Council of China, 2016b. Notice of two Ministries on Printing and Distributing the Action Plan for Urban Adaptation to Climate Change (in Chinese: 两部门关于 印发城市适应气候变化行动方案的通知) [online]. February. Available from: http://www.gov.cn/xinwen/ 2016-02/17/content_5042426.htm

Supreme People's Court of China, 2015. Decision of the CCCPC on some major issues concerning comprehensively deepening the reform [online]. October. Available from: http://english. court.gov.cn/2015-10/08/content_22130532.htm

The Intergovernmental Panel on Climate Change (IPCC), 2014. Summary for policymakers. In: C.B. Field et al., eds. Climate Change 2014: Impacts, Adaptation and Vulnerability Contributions of the Working Group II to the Fifth Assessment Report of the Intergovernmental Panel on Climate Change. Cambridge: Cambridge University Press, 1-32.

Toonen, T., 2010. Resilience in public administration: the work of elinor and vincent ostrom from a public administration perspective. Public administration review, 70 (2), 193-202. doi:10.1111/j.1540-6210.2010.02147.x

Trochim, W.M., et al., 2006. Practical challenges of systems thinking and modeling in public health. American journal of public health, 96 (3), 538-546. doi:10.2105/ AJPH.2005.066001

United Nations Convention Framework on Climate Change (UNFCCC), 2012. Guangzhou bus rapid transit system | China [online]. Available from: https://unfccc.int/cli mate-action/momentum-for-change/urban-poor/guangz hou-bus-rapid-transit-system

Walsh, J., et al., 2014. Chapter 2: our changing climate. In: J. M.Melillo, T.C. Richmond and G.W. Yohe, eds. Climate Change Impacts in the United States: The Third National
Climate Assessment, May. U.S. Global Change Research Program, 19-67. doi:10.7930/J0KW5CXT

Wang, A., 2015. Chinese state capitalism and the environment. In: C. Milhaupt and B. Liebman, eds. Regulating the visible hand? The institutional implications of Chinese state capitalism [online]. UCLA School of Law, Public Law Research Paper No. 15-52. Available at SSRN: https://ssrn.com/abstract $=2597411$

Williams, J.C., et al., 2010. Lessons learned in systems thinking approach for evaluation planning. Journal of public health management and practice, 16 (2), 151-155. doi:10.1097/PHH.0b013e3181c6b50d

Wilson, J.Q., 1974. The politics of regulation. In: J.W. McKie, ed. Social responsibility and the business predicament. Washington: The Brookings Institution, 135-168.

World Health Organization, 2016. Ambient air pollution: a global assessment of exposure and burden of disease [online]. World Health Organization. ISBN: 9789241511353. Available from: https://apps.who.int/ iris/handle/10665/250141

Xiang, J.J., et al., 2017. Association between dengue fever incidence and meteorological factors in Guangzhou, China, 2005-2014. Environmental research, 153, 17-26. doi:10.1016/j.envres.2016.11.009

Xinhua, 2019. Guangzhou wins C40 cities awards for green technology solution [online]. 10 October. Available from: http://www.xinhuanet.com/english/2019-10/11/c_ 138462004.htm

Zhang, R., et al., 2017. Trends of heat waves and cold spells over 1951-2015 in Guangzhou, China. Atmosphere, 8, 37. doi:10.3390/atmos8020037

Zhang, P., et al., 2018. Characteristics of summer high temperature heat waves in Guangdong and Guangxi from 1960 to 2015 (in Chinese: 1960-2015 年两广地区 夏季高温热浪变化特征). Journal of Zhejiang University Science Edition. Issue: 1.

Zhou, S.X. / State Council of China, 2014. Zhou Shengxian chairing the executive meeting of the Ministry of Environmental Protection (in Chinese: 周生贤主持召开 环境保护部常务会议) [online]. April. Available from: http://www.gov.cn/xinwen/2014-04/10/content_ 2656594.htm 